\title{
Oral health in patients with diabetes mellitus type 2 from the faculty of dentistry in San Francisco de Campeche 2016
}

\section{Salud oral en pacientes con diabetes mellitus tipo 2 de la facultad de odontología en San Francisco de Campeche 2016}

\author{
ROSADO-VILA, Graciella $\dagger$, ZAPATA-MAY, Rafael, SANSORES-AMBROSIO, Fatima and VIDAL- \\ PAREDES, Jorge
}

Universidad Autonoma de Campeche, Faculty of Odontology and Faculty of Nursing, San Francisco de Campeche, México

ID $1^{\text {st }}$ Author: Graciella, Josefa, Rosado-Vila / ORC ID: 0000-0002-8688

ID $1^{\text {st }}$ Coauthor: Rafael Zapata-May / ORC ID: 0000-0002-3750

ID $2^{\text {nd }}$ Coauthor: Fátima, Sansores-Ambrosio / ORC ID 0000-0001-5403-4802

ID $3^{\text {rd }}$ Coauthor: Jorge, Vidal-Paredes / ORC ID: 0000-0002-4474-3733

Received October 17, 2019; Accepted December 03, 2019

\begin{abstract}
Abstrat
Introduction: Insulin is a hormone secreted by the pancreas that has the function of controlling blood sugar concentration. The most common type of diabetes is type 2 which occurs 90 to $95 \%$ of cases. The most frequent alterations at the stomatological level are periodontal disease, gingivitis, caries, xerostomia (dry mouth syndrome), so there is a need to investigate how susceptible patients are to suffer from this disease and to be able to take the necessary preventive measures. had similar plaque levels. RESULTS: The sample studied corresponded to a total of 100 patients, 49 female (49\%), and 51 male (51\%). The average age of the sample was 54.89 years \pm 10.85 years with a range of ages between 40 and 70 years. The most representative age group was the group of 40 to 50 years with $39 \%$, followed by the group of 51-60 years with $37 \%$ and the group of $61-70$ years with $24 \%$. In the Gingival index it was found that $45 \%$ of the patients presented mild gingivitis, $13 \%$ moderate gingivitis and $21 \%$ severe gingivitis.

Keywords: diabetes, periodontal disease, gingivitis,

Resumen

Introducción: La insulina es una hormona segregada por el páncreas que tiene la función de controlar la concentración de azúcar en la sangre. La diabetes más común es la tipo 2 en el 90 o $95 \%$ de los casos. Las alteraciones más frecuentes a nivel estomatológico son la enfermedad periodontal, gingivitis, caries, xerostomía y síndrome de boca ardiente, por lo que surge la necesidad de investigar que tan susceptibles son los pacientes que sufren esta enfermedad y poder tomar las medidas preventivas necesarias. Resultados: La muestra estudiada correspondió a un total de 100 pacientes, 49 del sexo femenino (49\%), y 51 del sexo masculino $(51 \%)$. La edad promedio de la muestra fue de $54,89 \pm 10.85$ años con un rango de edades entre 40 y 70 años. El grupo etáreo más representativo fue el grupo de 40 a 50 años con $39 \%$, seguido del grupo mayor a 51-60 años con 37\% y el grupo menor de 6170 años con $24 \%$. En el índice Gingival se encontró que, el $45 \%$ de los pacientes presentó gingivitis leve, el $15 \%$ gingivitis moderada $13 \%$ y el $21 \%$ gingivitis severa.
\end{abstract} prevalence.

Diabetes, Periodontal Disease, Gingivitis, Prevalence
Diabetes, Enfermedad Periodontal, Gingivitis, Prevalencia 


\section{Introduction}

This work was carried out with the purpose of being able to investigate more about the oral health status of type 2 diabetic patients. Diabetes is an autoimmune and metabolic disease characterized by selective destruction of the beta cells of the pancreas causing an absolute insulin deficiency. Insulin is a hormone secreted by the pancreas that has the function of controlling blood sugar concentration. Insulin stimulates body tissues to absorb the glucose they need as fuel. The most common diabetes is type 2 in 90 or $95 \%$ of cases. The most frequent alterations at the stomatological level are periodontal disease, gingivitis, caries, xerostomia and burning mouth syndrome, so there is a need to investigate that so susceptible are the patients who suffer from this disease and be able to take the necessary preventive measures. This research focused on the oral status in type 2 diabetic patients with emphasis on the CPOD index, the gingival index, the presence or absence of removable and fixed prostheses. What is the oral health status of patients with type 2 diabetes mellitus who go to the dental faculty clinics at the Autonomous University of Campeche in the City of San Francisco de Campeche?

\section{Theoretical Framework}

According to the world diabetes association, more than 371 million people have diabetes, this number is increasing in each country, half of the world's population does not know that they have diabetes In Mexico the National Prevalence $14.3 \%$ in the population aged 20 to 69 , about 9 million people with diabetes INEGI statistics nationwide in the state of Campeche. During 2011, according to the SSA, the percentage of hospital discharge in men is $4.4 \%$ and in women 2.1 percent.

Diabetes is a disorder in the way in which the human body uses the glucose we obtain when ingesting food, producing an elevation of blood glucose levels known as hyperglycemia. The human body needs energy to fulfill its functions and to be able to carry out our daily activities. We obtain this energy from the food we consume. By digestion, food is degraded and as a final product they are converted into glucose, which is the main energy source of the cells. The pancreas is a gland located behind the stomach.
Among its many functions is the task of producing insulin, a hormone generated by beta cells that are located in the Islets of Langerhans, the function of insulin is to make it possible for glucose to enter the cells. Under optimal conditions, the production of insulin in the body depends on the accumulation of glucose in the blood, thus, when the glucose rises, the production of insulin is activated. Diabetes occurs when: - The amount of insulin produced by the pancreas is not enough to meet the body's needs. When the insulin that is produced does not have the effect that it should regularly have. When the pancreas stops producing insulin completely. Types of diabetes: According to the International Classification of Diseases the types of diabetes are: Type 1 diabetes: Formerly known as juvenile and / or insulin-dependent diabetes, it is a condition of autoimmune origin, this means that beta cells, responsible for producing insulin, are unknown and destroyed by the immune system itself responsible for protecting the body against viruses, bacteria and diseases.

This process of self-destruction is gradual, and the symptoms begin when a large part of the cells have already been eliminated. It has been possible to identify that this can begin several years before the person with diabetes is diagnosed. If so, it is believed that it happens due to hereditary factors and that it manifests itself from a trigger that ends up manifesting itself in diabetes, but the precise reason why this condition occurs is still unknown. This type of diabetes is 10 times less frequent than type 2. It is typically characterized by its early onset, before 20 years of age. Type 2 diabetes: Before adult and / or non-insulin-dependent call. This type of diabetes begins when the liver produces excess glucose and at the same time, tissues (mainly muscle) decrease the use of insulin, which causes high blood glucose levels.

This is called "insulin resistance" (it is a defect in the use of insulin) or also because insulin production is no longer sufficient and is triggered by different reasons such as: Obesity, sedentary life, poor diet in most In cases the hereditary factor is decisive. It is a little symptomatic disease, so its diagnosis is made in about $50 \%$ of cases by laboratory tests requested for another cause and not by clinical suspicion. 
The scarce classic symptomatology determines that with high frequency it is diagnosed late and in the presence of chronic complications. Gestational diabetes: It occurs during pregnancy in a woman who did not previously have diabetes. In this case, it is also insulin resistance. During pregnancy the body undergoes very intense hormonal changes and in gestational diabetes these hormones produce the inverse effect to insulin, raising blood glucose. Most often this condition disappears at the end of pregnancy, but there are cases in which diabetes remains and is considered as type 2 diabetes. Other Specific Types: Hyperglycemia occurs as a result of pancreatic disorders associated with medications or chemicals, endocrinopathies, disorders of insulin receptors, infections or other genetically associated syndromes and others.

\section{Approach}

In type 2 diabetes 2 alterations are associated: a decrease in the action of insulin, with an alteration of the function of the beta cell that is initially able to respond with an increase in insulin production (hence the levels of these are elevated or normal in order to compensate for the deficit of their action) but later insulin production is becoming insufficient. However, in type 1 diabetes, the alteration occurs at the level of beta cells, so insulin levels are very low, which is why the levels of C-peptide (which is secreted with insulin) are normal or high in Type 2 and type 1 diabetes are usually very low.

According to the Official Mexican Standard NOM-015-SSA2-19994: For the prevention, treatment and control of Diabetes the diagnosis of diabetes is established if it meets any of The following criteria: Presence of Classic symptoms and casual blood glucose> 200mg / dl., Fasting Plasma Glycemia> $126 \mathrm{mg}$ / dl., Blood glucose> $200 \mathrm{mg} / \mathrm{dl}$, two hours after oral loading of $75 \mathrm{~g}$. of dissolved glucose in water.The clinical characteristics, signs and symptoms of the patient with diabetes vary, depending on the specific type of the disease, but in general they include: polyuria, polydipsia, polyphagia, weight loss and asthenia.
The symptoms of type 2 diabetic can be classified as: Acute: Acute metabolic complications in Type 2 Diabetes Mellitus, mainly include the presence of 2 fundamental clinical conditions: As a non-ketosic hyperosmolar diabetic CDHNC and hypoglycemia secondary to the treatment of diabetes with insulin-secreting drugs and / or insulin. Chronic: Chronic complications of type 2 diabetes mellitus can be broadly subdivided into 2 categories: Ophthalmopathy microvascular complications. nephropathy and neuropathy.

The Macrovascular coronary heart disease, cerebrovascular and peripheral vascular disease. criteria of a patient with a good control of diabetes mellitus healthy and balanced nutritional regime, medications in the indicated doses-Insulinotherapy, exercise regularly, check blood glucose levels regularly, a blood glucose value within the limits of $80-130 \mathrm{mg} /$ dlcriteria of a patient with poor control of diabetes mellitus fatigue and weakness, numbness of hands and feet, blurred vision, dry skin, frequent need to urinate, insatiable thirst, dental mobility, high blood glucose of 200,300 or more than $1000 \mathrm{md}$ / dl.

The association between diabetes and inflammatory periodontal diseases has been extensively studied for more than 50 years. It is known that the prevalence of type $2 \mathrm{DM}$ increases with age, as there are older populations, the global prevalence increases. International investigations agree that as age increases, individuals move from a lifestyle marked by physical activity. and caloric restriction to another characterized by sedentary lifestyle and high caloric intake.

This predisposes to suffer said disease. In addition, type 2 DM increases its frequency with age due to a loss of the mass of beta cells in a genetically labeled pancreas. According to the bibliography consulted, the age group that brings together the largest number of patients with Diabetes are adults between 40 and 59 years old, followed by the group from 60 to 79 years old and the group from 20 to 39. On the other hand, in relation to gender, the total number of patients with Diabetes is similar between the two genders. The determination of the risk of dental caries is difficult due to the existence of complex interactions between multiple factors. 
DM increases the risk when combined with poor oral hygiene, cariogenic diets (it is not determined on the basis of sugar content, but several factors must be considered), among others.In patients with DM, when they have hyperglycemia, it is observed a salivary viscosity, a factor that predisposes to caries due to viscous saliva is less effective in carbohydrate clearance. The risk of dental caries changes throughout the person's life, as the risk factors from which DM does not escape change. As age increases and there is a deficiency in oral hygiene, there is an increased accumulation of dentobacterial plaque, which reduces the diffusion coefficient of acids formed by fermented microorganisms.

This facilitates the demineralization process and raises caries risk, especially in people with a high number of cariogenic microorganisms. When age increases the prevalence of periodontitis is higher. This is due to the effect of other factors over time and not a consequence of aging. It is greater in the diabetic patient due to decreased resistance to infection, vascular changes, altered oral bacterial flora, among others. .Studies of diabetes and periodontal diseases.

The relationship between diabetes and periodontal disease has been the subject of more than 200 articles published in English in the last 50 years, varying the clinical and radiological criteria used to assess the prevalence of periodontal disease, the extent and severity; evolution of the standards for the degree of glycemic control, and methods to assess the change in complications associated with diabetes. In addition, researchers and clinicians should be careful when comparing the results of different studies, since research has focused on varied populations and has often included a relatively small number of subjects or controls lacking. Symptoms of gingivitis: Red and swollen gums. Bleeding gums are not healthy. Even if your gums only bleed when you brush too hard, any bleeding symptoms are not normal. White or yellow pus around the gums. Teeth that are longer and gums that have receded from the teeth. A general evaluation of the available data suggests that diabetes is a risk factor for gingivitis and periodontitis. In a classic study of diabetes and gingivitis reported more than 30 years ago, the prevalence of gingival inflammation was higher in children with type 1 diabetes than in children without diabetes who had similar plaque levels.
Ervasti and colleagues observed greater gingival bleeding in patients with poorly controlled diabetes than in control subjects who do not have diabetes or in people with wellcontrolled diabetes. Subjects with type 2 diabetes also had greater gingival inflammation than control subjects who did not have diabetes, the highest level of gingivitis was found in patients with poor glycemic control. The appearance of type 1 diabetes in children has been associated with an increase in gingival bleeding, while improving control of blood sugar levels after initiation of insulin therapy resulted in decreased gingivitis.

The use of an experimental gingivitis protocol, a longitudinal study Recent showed faster and more severe gingival inflammation in adult patients with type 1 diabetes than in control subjects without diabetes, despite qualitative similar and quantitative bacterial plaque characteristics, suggesting a hyperinflammatory gingival response in people with diabetes. Possible signs of periodontal disease or periodontitis include tooth sensitivity, chewing pain, bleeding or red gums, and bad breath. Treatment: The treatment of severe periodontal disease can include a deep cleaning procedure called scraping and root brushing, in which the dentist removes tartar above and below the gum line and smoothes the rough points of the roots Dental, where the causative bacteria of plaque have to accumulate.

Most of the evidence also suggests that diabetes increases the risk of developing periodontitis. In a classic cross-sectional study, type 1 diabetes is associated with a five-fold prevalence of periodontitis in adolescents. A recent case-control study confirmed that insertion loss is more frequent and extensive in children with diabetes than in children who do not have diabetes. In addition, epidemiological research supports an increase in the prevalence and severity of insertion loss and bone loss in adults with diabetes. A multivariate risk analysis showed that subjects with type 2 diabetes have increased the chances of have periodontitis compared to subjects without diabetes, after adjusting for confounding variables such as age, gender and oral hygiene measures. 
A dental prosthesis is an artificial element intended to restore the anatomy of one or several teeth, also restoring the relationship between the jaws, while returning the vertical dimension, and replacing the teeth Diabetic patients are more prone to loss Dental therefore are candidates for oral prostheses either Mucosoportadas or adjusted. The literature reflects controversial aspects regarding the role of certain factors as well as their possible way of acting. Among the most important local factors in the development of oral lesions appear to be traumatic ones, poor oral hygiene and dry mouth in diabetic patients.

The first ones include burns, nibbled mucosa, maceration, local candy abuse, local effect of tobacco and the action of prostheses, which, being poorly adapted, cause continuous microtrauma on the supportive mucosa that they cover. Incorrect hygiene of the prosthesis and oral cavity promotes the accumulation and proliferation of microorganisms causing the imbalance of the oral microflora and may allow the action of opportunistic microorganisms such as Candida albicans.

The prostheses can be: Dentosoportadas: Those that are supported by the abutment teeth, or remnants, of the patient, which are natural teeth that it still retains. The teeth can retain their structure completely, or they can be (in the vast majority of cases) teeth previously carved by the dentist. Dentosoportadas are fixed prostheses. Mucosoportadas: Those that are supported on the alveolar process, in contact with the gum which is a fibromucosal tissue. Fully Mucosupported prostheses are the typical "dentures" (complete acrylic resin prostheses). Auto-supports: Those that combine the two types of supports mentioned above, that is, they are supported both in the patient's remaining teeth and in the alveolar process. They are metal prostheses, partial resin prostheses, and mixed prostheses. Implanted supports: Those that are supported by surgical implants (implanted prostheses).

\section{Justification}

A diabetic patient is considered high risk due to his systemic condition in a dental practice compared to a systemically healthy patient. Recent studies also indicate that there is a vicious cycle between diabetes and advanced gum disease.
People with diabetes are not only more susceptible to advanced gum disease, but they can affect blood glucose control and contribute to the progression of diabetes. Studies indicate that people with diabetes are at an increased risk of oral health problems such as gingivitis gum disease in its initial stage and periodontitis advanced gum disease. People with diabetes are at a higher risk of periodontitis because they are generally more susceptible to bacterial infections and are less able to fight the bacteria that invade the gums.

Therefore, this study aims to know what is the main risk factor that these patients run in order to be able to emphasize the preventive measures they may have and make patients with diabetes mellitus aware of oral diseases that are very easy in their situation to obtain and that can lead to aggravate your systemic situation by the fact of not having a healthy oral health status.

\section{Methodology}

It is a non-experimental, descriptive, transversal, projective, non-probabilistic sample selected for convenience, not blinded and without controls. Time Delimitation The time covered by the study was from January to September 2014. Study design: Cross-sectional study: The total of 100 patients with type 2 diabetes, 49 women and 51 men who attended the study were included in the sample. stomatology consultation in the clinics of the faculty of dentistry of the UAC in the study period.2014

\section{Characteristics Clinical signs}

\section{Absence of inflammation None}

1 Slight swelling Slight color and texture change 2 Moderate inflammation Moderate brightness, redness, edema and hypertrophy, blood on probing

3 Severe inflammation Tendency to spontaneous bleeding. ulceration

The following table summarizes the gingival index according to Loe and Silness. MEASUREMENT SCALE: categorical.

Periodontitis conceptual definition: Periodontitis It is a disease that can initially occur with gingivitis, and then continue with a loss of collagen insertion, gingival recession and even bone loss, in the case of not being treated, leave the tooth without bone support. 
The loss of such support implies the irreparable loss of the tooth itself operational definition: categories: 0- Absence, 1- mild, 2moderate, 3-Severe The data were collected in the clinical file of the faculty of dentistry of the UAC, once carried out the corresponding procedures with the authorities of the campus. The review was carried out each of the previously selected medical records of patients with type 2 diabetes mellitus. In each patient history a methodical inspection of symptoms and treatments performed on the patient was performed .To obtain data, the CPOD odontometer was used. The statistic is descriptive; the measures of central tendency and dispersion appropriate for each variable according to their distribution are described and the summary data is presented in tabular and graphical form.

\section{Results}

The sample studied corresponded to a total of 100 patients, 49 female $(49 \%)$, and 51 male (51\%). The average age of the sample was 54.89 \pm 10.85 years with a range of ages between 40 and 70 years. The most representative age group was the group of 40 to 50 years with $39 \%$, followed by the group older than 51-60 years with $37 \%$ and the group less than 61-70 years with $24 \%$. In the Gingival index it was found that $45 \%$ of the patients presented mild gingivitis, $15 \%$ moderate gingivitis $13 \%$ and $21 \%$ severe gingivitis.

The Periodontal Disease Index showed that $20 \%$ had severe periodontitis and $11 \%$ had mild periodontitis, and $54 \%$ did not present the disease. It was observed that $39 \%$ of the patients had some fixed prosthesis, and $16 \%$ had a removable prosthesis. The statistical analysis regarding gender analysis did not show any statistically significant relationship. It was also found that there is a highly significant relationship between gingivitis, periodontitis and tooth decay. Therefore, the greater the presence of gingivitis, the greater the prevalence of periodontitis and dental caries.

\section{Discussion}

$\mathrm{DM}$ is a systemic disease that involves a diverse clinic and presents various manifestations in the oral cavity. World literature reports that its highest prevalence occurs in the female gender. In the present study, the majority of patients were male $(51 \%)$ with an average age of $40-70$ years. Possibly this is due to the fact that type 2 $\mathrm{DM}$ is diagnosed in adulthood in most cases. In accordance with this investigation where all the patients were type 2 diabetics.

In other investigations it is expressed that gingivitis occupies the first place of the pathologies found in DM; which was evidenced in the patients of this study. In others, despite the high incidence of gingivitis, this does not become the most frequent alteration. At the same time, studies indicate that periodontitis is a frequently reported oral disease in diabetic patients; as found in this investigation. In this regard, it has been shown that there is a bidirectional relationship between DM and the

\section{Age}

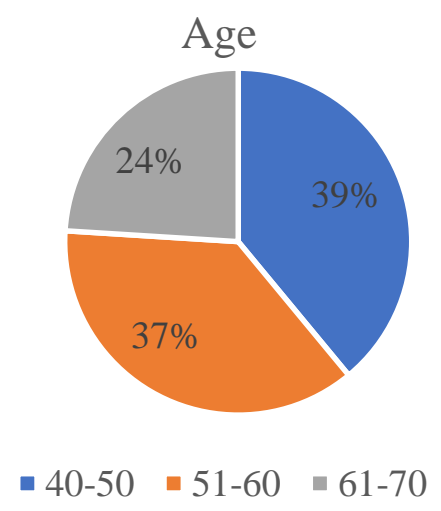

Graph 1

Periodontitis Chronic infection with large negative bacteria of the dentobacterial plaque leads, in diabetic patients, to the increase in insulin resistance of the tissues and to the increase in hyperglycemia. This can result in the accumulation of irreversibly altered proteins, which bind to receptors in macrophages and induce the excessive release of proinflammatory cytosines, leading to a more catabolic situation. Chronic periodontitis associated with the presence of local irritants constantly stimulates the defense of periodontal tissues. 
So it is believed that the possible relationship between periodontitis and certain systemic conditions such as DM, may be given in the immune response. Most research on this relationship has focused on how this disease can affect periodontal conditions.

The inverse relationship is also studied today; that is, how periodontal diseases affect the metabolic situation. In this sense, it has been determined that periodontal treatment contributes to a positive control of blood glucose levels, which leads to a decrease in the complications of DM. Thus, the well-controlled diabetic patient has a tissue response and a normal immune defense against infections. Therefore, the best method we have is the prevention of periodontal conditions in the diabetic, in order to achieve better care of the oral cavity of these patients.

Dental caries is another oral clinical manifestation that, for some authors It has a high incidence in diabetic patients, which is consistent with our results. Unlike a report made in 2003, which reports this pathology in a smaller percentage. In addition, it is indicated that diabetic patients have a high prevalence of cervical caries. In our case, only a low occurrence of cervical caries was detected, within the total number of caries detected. The majority of oral lesions in diabetic patients are located in soft tissues. Among the frequent clinical findings in the diabetic patients studied are: the saburral tongue and the fissured tongue. Research shows that there is a variability in the prevalence of these two clinical manifestations. Some studies report a low prevalence, unlike the high percentage found in this study.

It is likely that the saburral language is not a characteristic alteration of DM, since it can be associated with multiple general and local factors and occurs both in systemically compromised and healthy people. Similarly, it is presumed that our findings in relation to the fissured tongue are due to the average age of the patients studied $(54.89 \pm 10.85$ years $)$, since the appearance of lingual fissures increases with age.

\section{CPOD}

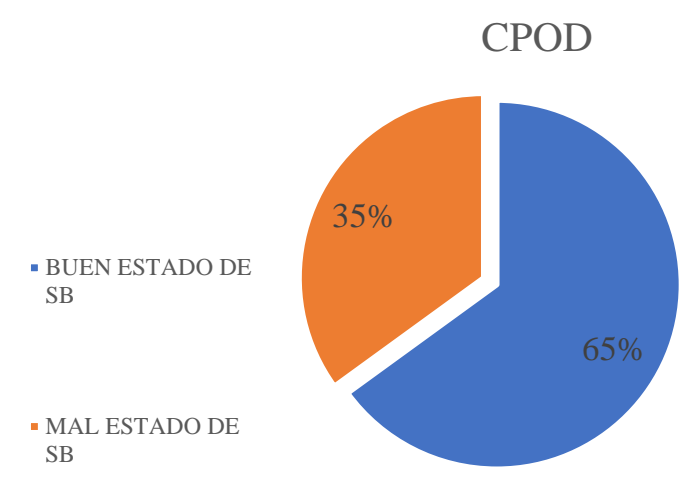

\section{Graph 2}

Xerostomia is one of the oral manifestations most commonly referred to by diabetic patients. According to some reports, it is described to a lesser extent; contrary to the high percentage that our results reveal. It is likely that this difference is due to the fact that in our study group the majority of patients were poly medicated it was common to observe that a patient had more than one disease, which in some cases can produce xerostomia as a side effect, as well as in the case of the use of antihypertensives. This entity is considered to trigger many alterations in the oral cavity; as well as the difficulty for chewing, tasting and swallowing food.

The high prevalence of xerostomia, saburral tongue and candidiasis could be a warning signal to make an early diagnosis of diabetic patients by the Dentist. This alteration was found significantly in the diabetic patients of our study, compared to other reports. Also, some studies indicate a low frequency of halitosis; while others have a high presence of this alteration, similar to that obtained in this study. It is likely that this high percentage of halitosis in patients may be due to the high frequency of periodontal disease and xerostomia.

The results of our study confirm that there is a highly significant relationship between periodontitis and age groups, the group being 41 to 60 years who presented the highest rate of periodontitis in accordance with another report. This indicates that, at a higher age of the patient with DM there is a greater predisposition to suffer from periodontal disease. For many years, experts raised the possibility that there were specific diseases of the diabetic that affected the mouth. Today we know that there are only differences in frequency of occurrence but there are no oral lesions exclusive to DM.

ROSADO-VILA, Graciella, ZAPATA-MAY, Rafael, SANSORESAMBROSIO, Fatima and VIDAL-PAREDES, Jorge. Oral health in patients with diabetes mellitus type 2 from the faculty of dentistry in San Francisco de Campeche 2016. Journal of Research and Development. 2019 


\section{Conclusion}

In this study conducted in patients with type 2 diabetes mellitus who attended the clinics of the Faculty of Dentistry of San Francisco de Campeche 2014, We can conclude that of the total of 100 patients included in the analysis The most representative age group was 40 to 50 years with (39\%) and according to the gingival index we found a prevalence of $21 \%$ severity of the disease in patients contrasting with $45 \%$ of patients who still have a mild level of the disease. Likewise, the periodontal disease index showed that $20 \%$ of patients have a severe level of oral disease, in addition to $39 \%$ of patients having fixed prostheses that in many cases are in poor condition or poorly adapted and only $16 \%$ use removable prostheses. It was also found that there is a highly significant relationship between gingivitis, periodontitis and CPOD index.

\section{Removable protesis}

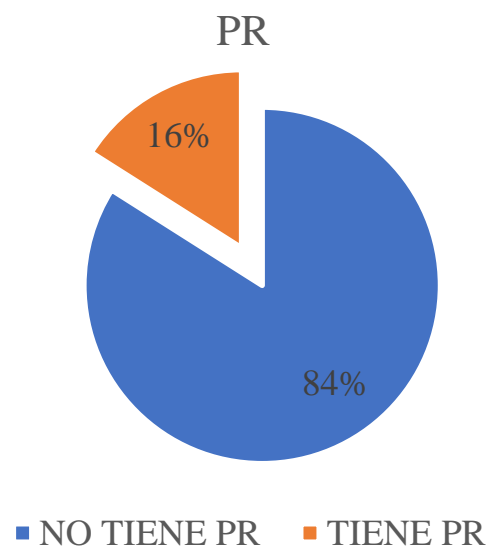

Graph 3

Therefore, the greater the presence of gingivitis, the greater prevalence of periodontitis, tooth decay and dental loss. No significant difference in gender was found. It is worth mentioning that the majority of the total patients mention that they do not have enough knowledge or information about the extreme care they should have when having DM in their body as an example the care of not having any infectious focus on the oral cavity.

Which predisposes to have high blood glucose levels and not being able to control them for no apparent reason even while carrying out a medical check-up does not give it enough importance when trying to preserve your dental organs until the moment of being able to swallow your food correctly or comfortably. As a personal recommendation.
I would like that, according to the results obtained in this investigation, greater emphasis was given to prevention talks in the faculty, especially to patients with diabetes mellitus on oral care since the moment they were diagnosed disease to patients; starting with a simple semiannual prophylaxis and constant checkups so that they can lead a good quality of life and have adequate glucose control.

\section{GINGIVITIS}

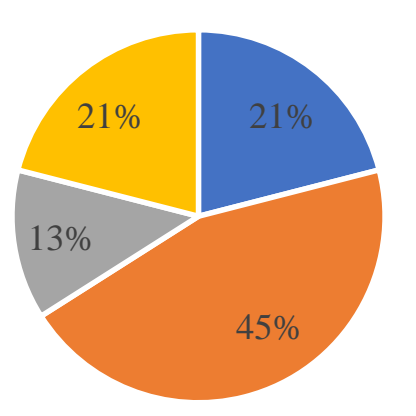

- AUSENCIA DE INFLAMACION

- INF. LEVE

- INF.

MODERADA

- INF. SEVERA

Graph 4

\section{PERIODONTITIS}

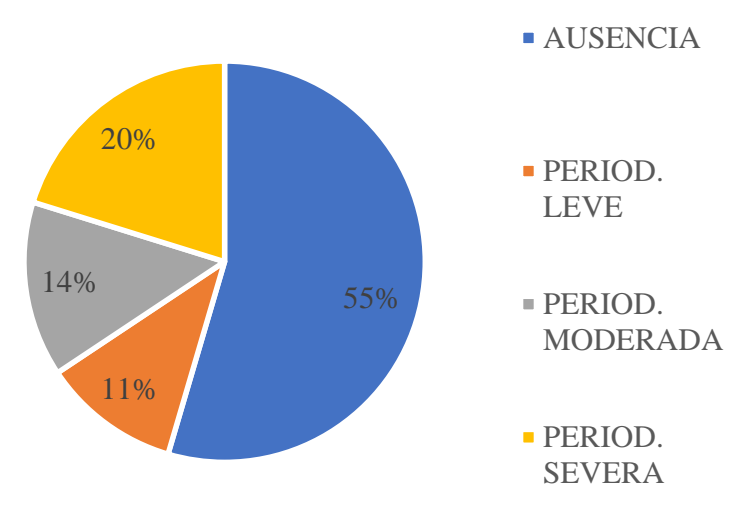

Graph 5

\section{References}

asociación mexicana de diabetes (Fuente ENSANUT 2006). (Visitado noviembre de 2013) se encuentra en http://www.amdiabetes.org/estadisticas_de_la_ diabetes.php

asociación mexicana de diabetes. (Fuente amd). Visitado noviembre 2013. Se encuentra en: http://www.amdiabetes.org/definicion_causas_t ipos_diabetets.php 
asociación mexicana de diabetes. (Fuente amd). Visitado noviembre 2013. Se encuentra en: http://www.amdiabetes.org/tipos_diabetets.php.

asociación mundial para la diabetes. Fuente: IDF Diabetes Atlas quinta edición actualización 2012 - (visitado noviembre de 2013) se encuentra en: http://www.idf.org/types-diabetes.

Brian, L. Periodontal disease and diabetes. A Two-way street. 2006, obtenible en JADA: http://jada.ada.org/cgi/content/abstract/137/sup pl_2/26S [Consulta: 04 de Noviembre del 2007]. CAD/CAM WorkNC Dental y ERP WorkPLAN» (en español)

Castellanos JL, Díaz LM. Gay O. Medicina en odontología en manejo dental de pacientes con enfermedades sistémicas. El Manual Moderno. México, 1996, 8:270-283.

Ceballos, A., Bullón, P., Gándara, J., Chimenos, E., Blanco, A., Martínez-Sahuquillo, A, García, A. Medicina Bucal Práctica. España: Editorial Danú, S. L.; 2000

Centro Nacional de Estadísticas de Salud. Chartbook sobre las tendencias en la salud de los estadounidenses: Tabla 55. Hyattsville, MD: Centro Nacional de Estadísticas de Salud, 2005. Disponible en: " www.cdc.gov / NCHS / hus.htm". Visitado noviembre 2013.

Cutler CW, Machen RL, Jotwani R, Iacopino AM. La inflamación y el apego pérdida aumentada gingival en pacientes diabéticos tipo 2 con hiperlipidemia J Periodontol 1999; 70 (11):. 1313 -21. CrossRefMedline.

Ervasti L, Knuuttila M, L Pohjamo, Haukipuro K. Relación entre el control de la diabetes y sangrado gingival J Periodontol 1985; 56 (3): $154-7$

García, E., Aranda, S., Cruz, S., Mondragón, A. Frecuencia de manifestaciones bucales en pacientes diabéticos tipo 2 de una Unidad de Medicina Familiar del IMSS. 2006, obtenible en Rev. Ciencia Clínica: http://www.imbiomed.com.mx/1/1/articulos.ph p?method=showDetail\&id_articulo $=41612 \& i d$ seccion $=59 \&$ id_ejemplar $=4259 \&$ id_revista $=11$ [Consulta: 08 de enero del 2008].
Garcia, E., Mondragón, A., Aranda, S., Bustamante, R. Oral mucosa symptoms, sings and lesions in diabetic patients. 2006, obtenible en Med Oral Patol Oral Cir Bucal: Obtenible en: http://scielo.isciii.es/pdf/medicorpa/v11n6/03.p df [Consulta: 04 de diciembre del 2007].

Guggenheimer J, Moore PA, Rossie K, Myers D, Mongelluzzo MB, Block HM, Weyant R, Orchard T. Insulin-dependent diabetes mellitus and oral soft tissue pathologies. I. Prevalence and characteristics of non-candidal lesions. 2000, obtenible en Oral Surg Oral Med Oral Pathol Oral Radiol Endod: http://www.ncbi.nlm.nih.gov/pubmed/1080771 3 [Consulta: 10 de enero del 2008].

Hans-Peter M. Periodontología. España: Manual moderno, 2006. ISBN: 9707292288

Hintao J, R Teanpaisan, Chongsuvivatwong V, Dahlen G, Rattarasarn C. Caries en superficie radicular y coronal en adultos con diabetes mellitus tipo 2. Tailandia. 2007, obtenible en Community Dent Oral Epidemiol. Disponible en:

http://www.ncbi.nlm.nih.gov/pubmed/1761501 7? ordinalpos=2\&itool=EntrezSystem 2.PEntrez. Pubmed.Pubmed_ResultsPanel.Pubmed_RVDo cSum [Consulta: 04 de diciembre del 2007].

INEGI /SSA .día mundial de la diabetes, fuente INEGI 2011.VISITADO NOVIEMBRE 2013 se encuentra en http://elsemanario.com/753/inegi-lanzaestadisticas-sobre-la-diabetes/.

Karjalainen K, Knuuttila M. La aparición de la diabetes y el mal control metabólico aumenta el sangrado gingival en niños y adolescentes con diabetes mellitus insulino-dependiente $\mathbf{J}$ ClinPeriodontol 1996; 23 (12): 1.060 -7.

Lalla E, Cheng B, Lal S, Tucker S, et al. Cambios periodontales en niños y adolescentes con diabetes:. Un estudio de casos y controles Diabetes Care 2006;

Martínez, E, Diabetes y Salud Bucal. Asociación de diabéticos Getafe. 2003, obtenible en: http://www.adgetafe.com/index 2.php?cat=25\&s $\mathrm{ub}=15 \& \mathrm{n}=0$ [Consulta: 04 de diciembre del 2007] 
Muñoz MA, Gómez C, Martínez RA, Vivas FP, Albarrán J, Hawkins F. Riesgo de infecciones y control metabólico en pacientes con diabetes mellitus tipo 2. An Med Intern 2004; 21-3:1-13.

Ogunbodede EO, Fatusi OA, Akintomide A, Kolawole K, Ajayi A. Oral health status in a population of Nigerian diabetics. 2005, obtenible en The Journal of Contemporary Dental Practice: http://www.thejcdp.com/issue024/ogunbodede/ ogunbodede.pdf [Consulta: 28 de enero del 2008].

pacientes con diabetes y enfermedad periodontal(fuente oral B) visitado diciembre del 2013 se encuentra en : http://www.oralb.com.mx/mexico/topics/pacien tes_con_diabetes_y_enfermedad_periodontal.as $\mathrm{px}$

Portal ERP SPAIN. «Proyecto de "fabricación abierta" de prótesis dentales con Rhodus NL, Vibeto BM, Hamamoto DT. Glycemic control in patients with diabetes mellitus upon admission to dental clinic: considerations for dental management. Quintessence Int 2005; 36-6: 474482 .

Salvi GE, Kandylaki M, Troendle A, Persson GR, Lang NP. Gingivitis experimental en diabéticos tipo 1: un estudio clínico y microbiológico controlado $\mathrm{J}$ ClinPeriodontol 2005; 32 (3):310 -6.

Sammalkorpi K. Glucose intolerance in acute infections. J Inter Med 1989; 225:15-19

Schmid MI, Ducan BB, Sharrett AR, Lindberg G, Savage PJ, Offenbacher S, Azambuja MI. Markers of inflammation and prediction of diabetes mellitus in adults: a cohort study. Lancet 1999; 353: 1649-1652.

Shlossman M, Knowler WC, Pettitt DJ, Genco RJ. . Diabetes mellitus tipo 2 y la enfermedad periodontal JADA 1990; 121 (4): 532 -6.

sintomas de la enfermedad periodontal (fuente abstrac oral B) visitado diciembre del 2013 se encuentra en: http://www.oralb.com.mx/mexico/topics/sintom as_y_cura_de_la_enfermedad_periodontal.aspx
Soell M, Hassan M, Miliauskaite A, Haïkel Y, Selimovic D. The oral cavity of elderly patients in diabetes. 2007, obtenible en Journal of Periodontology: http://www.joponline.org/doi/abs/10.1902/jop.2 007.060492 [Consulta: 04 de diciembre del 2007]

Svenson KL, Lundquist G. Impaired glucose handling in active rheumatoid arthritis: relationship to the secretion of insulin and counter regulatory hormones metabolism. Clinical and experimental 1987; 36:940-943.

Torres, M., \& Dìaz, M., "La diabetes mellitus y su vinculación en la etiología y patogenia de la enfermedad periodontal. 2007, obtenible en Gaceta Médica Espirituana: http://bvs.sld.cu/revistas/gme/pub/vol.9.(2)_22/ p22.html [Consulta: 04 de diciembre del 2007] tratamiento de la enfermedad periodontal o periodontitis (fuente oral B) visitado diciembre del 2013 se encuentra en: http://www.oralb.com.mx/mexico/topics/ _cura_de_la_enfermedad_periodontal.aspx

Ueta E, Osaki T, Yoneda K, Yamamoto T. Prevalence of diabetes mellitus in odontogenic infections and oral candidiasis: an analysis of neutrophil suppression oral, 1993, obtenible en Oral Pathol Med, Apr; 22(4):168-174: http://www.ncbi.nlm.nih.gov/sites/entrez [Consulta: 04 diciembre del 2007].

Vernillo, A. Dental considerations for the treatment of patients with diabetes mellitus. 2003, obtenible en American Dental Association:

http://jada.ada.org/cgi/content/full/134/suppl_1/ 24S [Consulta: 22 de enero del 2007]. 